Original Research Paper

\title{
Statistical Analysis of Geothermal Data of an Oil Field, in Parts of Niger Delta, Nigeria
}

\author{
Emujakporue Godwin Omokenu and Leonard I. Nwosu \\ Department of Physics, University of Port Harcourt, Rivers State, Nigeria
}

\author{
Article history \\ Received: $19-08-2016$ \\ Revised: 22-09-2016 \\ Accepted: 23-09-2016 \\ Corresponding Author: \\ Emujakporue Godwin \\ Omokenu \\ Department of Physics, \\ University of Port Harcourt, \\ Rivers State, Nigeria \\ Email: owin2009@yahoo.com
}

\begin{abstract}
Geothermal gradient and heat flow were computed from bottom hole temperatures in an oil field in Niger Delta, Nigeria. The statistical analysis of computed geothermal data was carried out. The computed geothermal gradient vary from $17.3 \pm 0.14$ to $24.33 \pm 0.70^{\circ} \mathrm{C} / \mathrm{Km}$ with an average of $22.24 \pm 0.57^{\circ} \mathrm{C} / \mathrm{km}$. The heat flow ranges from $38.06 \pm 0.31$ to $56.39 \pm 2.41 \mathrm{mWm}^{-2}$ with an average of $50.15 \pm 1.25 \mathrm{mWm}^{-2}$. The computed variance of the geothermal gradient and heat flow are 0.499 and 2.447 respectively. The standard deviation for the geothermal gradient and heat flow are also 0.79 and 1.564. The values of the geothermal gradient and heat flow are low in the south and high in the northern parts of the field. The geothermal values increase towards the north. The possible causes of geothermal anomalies are variation in thermal conductivity, presents of geological structures such as growth faults and rollover anticlines and movement of fluid in the subsurface. The least geothermal gradient and heat flow values occur in the edge of the south east region. The region with high heat flow may be attributed to low sedimentary thickness while area with low heat flow may be associated with high sedimentary thickness. The geothermal analysis shows that the sediments in the area has attained hydrocarbon generation stage of temperature interval of 150 to $300^{\circ} \mathrm{F}(65$ to $150^{\circ} \mathrm{C}$ ). In the concept of the hydrocarbon-liquid window, the depth range within which liquid hydrocarbons are likely to be present is $1550-4500 \mathrm{~m}$.
\end{abstract}

Keywords: Bottom Temperature, Heat Flow, Geothermal Gradient, Statistical Analysis, Hydrocarbon Generation

\section{Introduction}

The study of subsurface temperature, geothermal gradients and heat flow is crucial in understanding the thermal maturation of sediments and the past thermal regimes in a basin. The temperature history of a sedimentary basin controls it's maturation and its subsequence conversion to hydrocarbon. The sources of heat in a sedimentary basin are the heat flow from the earth's interior and those generated by the radioactive elements present in the sediments. The thermal history of a sedimentary basin is related to the processes of basin formation (Sleep, 1971).

Heat flow is usually transfer from the basement rock into the overlying sedimentary sequence. The temperature in sedimentary basin increases downwards with depth while heat is transported upwards by a process known as heat flow. Heat is usually transported by conduction, convection and radiation depending on the medium. Heat flow is mainly transported in sedimentary basin by conduction.
Hydrocarbon exploration has been going on for about sixty years now in the Niger Delta and it is necessary to assess the present thermal regime of the basin. The estimated present day temperature data will be used for evaluating the thermal structure of the field. The drilling of high risk depths and targets such as turbidite and channel filled facies of the Akata Formation requires a good understanding of geothermal properties. The results obtained will help in predicting temperatures before drilling production wells in the area, so that suitable drilling bits, well mud and cementing programmed could be properly designed. This study will also be useful in basin analysis for evaluating the hydrocarbon maturation status.

The Niger delta sedimentary basin of Nigeria has been a focus of so many geological studies in the past years because of the petroleum potentials in the area. Most of these studies includes geology and geophysics. Similarly, some geothermal studies have also been carried out in the Niger Delta (Nwachukwu, 1976; 
Avbovbo, 1978; Evamy et al., 1978; Chukwueke et al., 1992; Akpabio et al., 2003; Ogagarue, 2007).

Nwachukwu (1976) computed geothermal gradient from about 1000 well logs in the Niger Delta basin and discovered that the geothermal gradients are lowest over the centre of the Niger Delta, approximately about 0.7 to $1.0^{\circ} \mathrm{F} / 100 \mathrm{ft}$ and increase to about $3^{\circ} \mathrm{F} / 100 \mathrm{ft}$ in the Cretaceous rocks in the north. Evamy et al. (1978) examined the hydrocarbon habitat of the Tertiary Niger Delta, the relationship between sand percentage, depth and temperature. They observed that geothermal gradient increases with reducing sand percentage from less than $1.0^{\circ} \mathrm{F} / 100 \mathrm{ft}\left(1.84^{\circ} \mathrm{C} / 100 \mathrm{~m}\right)$ in the continental sands to about $1.5^{\circ} \mathrm{F} / 100 \mathrm{ft}\left(2.73^{\circ} \mathrm{C} / 100 \mathrm{~m}\right)$ in the paralic section, to a maximum of about $3.0^{\circ} \mathrm{F} / 100 \mathrm{ft}\left(5.47^{\circ} \mathrm{C} / 100 \mathrm{~m}\right)$ in the continuous shales of the Niger Delta. Avbovbo (1978) used bottom hole temperatures and production reservoir temperatures data from southern Nigeria basin to determine geothermal gradients in the Niger Delta. He observed an increase in temperature gradient to the Northeast, with the highest gradient of $3.00^{\circ} \mathrm{F} / 100 \mathrm{ft}$ occurring in the Awgu-Enugu-Nsukka axis of the Anambra Basin, fairly high geothermal gradients of approximately 1.60 to $2.60^{\circ} \mathrm{F} / 100 \mathrm{ft}$ in the Calabar-Onitsha-Benin axis of the Coastal region and low gradients of 1.20 to $1.40^{\circ} \mathrm{F} / 100 \mathrm{ft}$ in the Warri-Port-Harcourt areas of the Niger Delta. He also observed maximum temperature gradient of about $1.80^{\circ} \mathrm{F} / 100 \mathrm{ft}$ in the offshore area. The maximum temperature gradient at the northeastern flank is about $2.60^{\circ} \mathrm{F} / 100 \mathrm{ft}$ and $2.20^{\circ} \mathrm{F} / 100 \mathrm{ft}$ at the eastern flank. Chukwueke et al. (1992) estimated the geothermal gradient and heat flow for the distal part of the Niger Delta. They discovered that the geothermal gradients and heat flow calculated from 33 wells range between 19$32^{\circ} \mathrm{C} / \mathrm{km}$ and $45-85 \mathrm{mWm}^{-2}$ respectively.

Ogagarue (2007) calculated heat flow for twenty-one wells in the western Niger Delta Basin. He observed that the heat flow varies between $27.6-68.3 \mathrm{mWm}^{-2}$, with an average of $43.92 \mathrm{mWm}^{-2}$. He also observed that the north-central part of the study area is characterized by high heat flow, which decreases towards the Niger Delta coast. Akpabio et al. (2003) determined geothermal gradients in the Niger Delta using continuous temperature logs from 260 wells and discovered that geothermal gradients in the continental section are lowest $\left(0.82^{\circ} \mathrm{C} / 100 \mathrm{~m}\right)$ in the central part of the delta, increases seaward to $2.62^{\circ} \mathrm{C} / 100 \mathrm{~m}$ and northward to $2.95^{\circ} \mathrm{C} / 100 \mathrm{~m}$. Onuoha and Ekine (1999) carried out a research on subsurface temperature variations and heat flow in the adjacent Anambra Basin. They obtained geothermal gradients and heat flow that varies from $25-$ $49.1^{\circ} \mathrm{C} / \mathrm{km}$ and $48-763 \mathrm{mWm}^{-2}$ respectively.

Statistics is the collection, organization, analysis and interpretation of data. These numbers are arranged into a few set of interpretable numbers. The summaries help to reduce the amount of data and to make it easier for decision and draw conclusions to be taken on the dataset. Statistical study also helps to obtain an overview of the data and its key characteristics (Cressie, 1993). This analysis of the data is known as Exploratory Data Analysis (EDA). The first step of data analysis is the determination of frequency distribution of the acquired data. This is done by characterizing the frequency distribution by mean and median and variability indicators such as the variance and standard deviation. Some of these parameters used for characterizing a sampling distribution especially are appropriate to the geological sciences (Davis, 1973; Hass and Jousselin, 1975).

Most of the geothermal studies in the area have little or no statistical analysis. Therefore, the objectives of this work are to compute geothermal gradient and heat flow of the field from measured bottom hole temperature and to statistically analyze the computed geothermal data.

\section{Summary of the Geology of the Studied Area}

The studied area is located within the Niger Delta sedimentary basin, Nigeria. The Niger Delta sedimentary basin is situated in the Gulf of Guinea. The development of the basin began in the Eocene accumulating sediments that now are almost $12 \mathrm{Km}$ thick. It is located in West Africa between latitude 3 and $6^{\circ} \mathrm{N}$ and longitude 5 and $8^{\circ} \mathrm{E}$. It is one of the world's most prolific petroleum producing Tertiary deltas that accounts for about $5 \%$ of the world's oil and gas reserves. The sedimentary basin comprises of three litostratigraphic units of variable geologic characteristics. These lithostratigraphy are classified as topset, foresets and bottomsets beds as revealed from seismic stratigraphy. The topset portion is a regressive continental unit called the Benin Formation, whereas the marine clay/shale of the Akata Formation is the bottomset portion of the delta depositional system. The foresets is the Agbada Formation and it is made up of alternation of sand and shale. The Agbada Formation contains hydrocarbon reservoirs sand while the over pressured shales act as seal to the reservoirs. Several researchers have worked on the stratigraphy, sedimentology, structural styles and the petroleum potential of the basin (Adesida et al., 1977; Avbovbo, 1978; Reijers, 1996; Reijers et al., 1997; Reijers, 2011; Ekweozor and Daukoru, 1994).

\section{Materials and Methods}

The data used for the study are bottom hole temperatures obtained from five oil wells in an oil field and base map of the studied field showing the well locations (Fig. 1). The bottom hole temperatures were recorded in the Fahrenheit scale and were converted to Celsius scale in this research work. Corrections was already applied to the data before it was released by the Company. The basic analysis applied to the temperature data are as follows. 


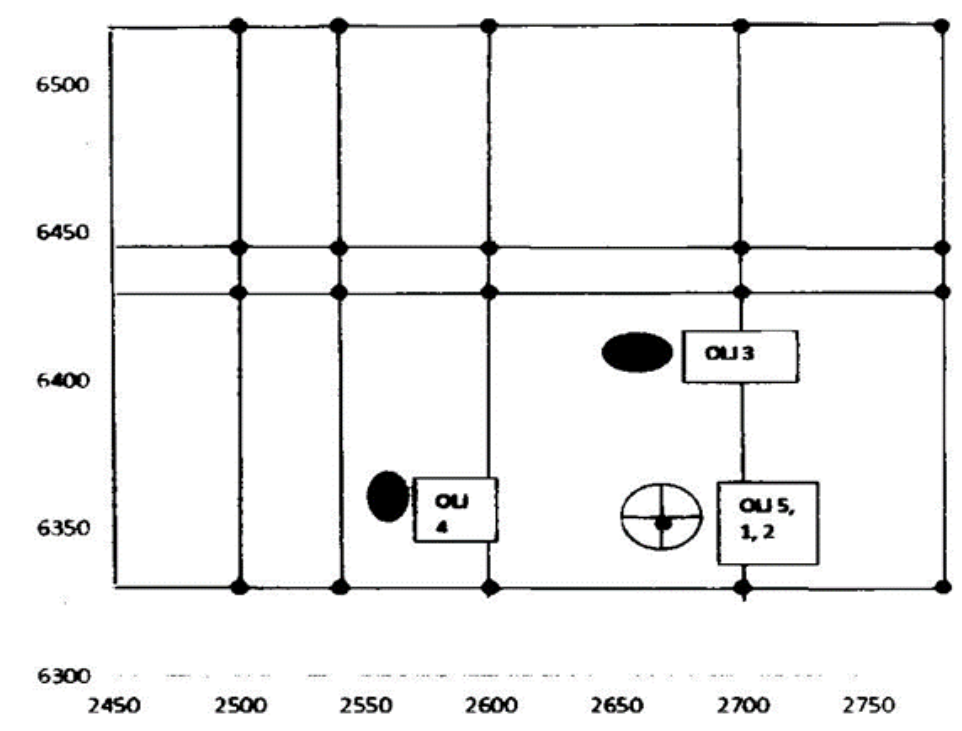

Fig. 1. Base map of the oil field showing well location

\section{Determination of Geothermal Gradient}

Geothermal gradient is a measure of the rate of change of temperature with depth. The geothermal gradient is computed by dividing the difference between the temperature of the formation at a given depth and mean annual surface temperature by the depth of the formation according to the empirical equation:

$$
T z=m Z+T_{0}
$$

Where:

$T z=$ Wellbore temperature in ${ }^{\circ} \mathrm{C}$ at depth $\mathrm{Z} \mathrm{km}$

$T_{0}=$ Mean surface temperature in ${ }^{\circ} \mathrm{C}$

$m=$ Geothermal gradient in ${ }^{\circ} \mathrm{C} / \mathrm{km}$

The average surface temperature for the Niger delta is $27^{\circ} \mathrm{C}$. The geothermal gradient is measured in ${ }^{\circ} \mathrm{C} / \mathrm{km}$.

\section{Determination of Heat Flow}

Heat flow is the product of thermal gradient and thermal conductivity (Beardsmore and Cull, 2001). The heat flow is computed from Fourier's one dimensional heat flow equation given as:

$$
Q=-K \frac{d T}{d Z}
$$

Where:

$$
\begin{aligned}
& Q=\text { Heat flow } \\
& K=\text { Thermal conductivity } \\
& \frac{d T}{d Z}=\mathrm{m}=\text { geothermal gradient }
\end{aligned}
$$

The negative sign in Equation 2 arises because the temperature is increasing in the positive depth direction while heat flows in the negative, $Z$ direction. Thermal conductivities of sand and shale used for this work were obtained from literature. The unit of heat flow $Q$ is Watts per square metre $\left(\mathrm{Wm}^{-2}\right)$.

\section{Statistical Analysis}

Basic statistical calculations were applied to the computed geothermal gradient and heat flow. The statistical techniques applied to the geothermal data in each well are.

\section{Average of Geothermal Data}

The average (mean) of the geothermal gradient and heat flow of the sample points in each borehole were calculated. This same technique was also applied for the geothermal data from the five wells. The average geothermal data was calculated by:

$m=\frac{1}{n} \sum_{i=1}^{n} X i=E(X)$

Where:

$$
\begin{array}{ll}
x & =\text { The value geothermal data } \\
n & =\text { The number of samples } \\
E[X] & =\text { The expected value } \\
m & =\text { Mean }
\end{array}
$$

\section{Variance of Geothermal Data}

The variance is a measure of spread. It is the average squared-distance of the data from the mean. It is obtained from the equation:

$S^{2}=\frac{1}{n} \sum_{i=1}^{n}(X i+m)^{2}$ 
Where:

$S^{2}=$ Variance

$M=$ Mean

$n=$ No of data

$x=$ Value of data

\section{Standard Deviation of Geothermal Data}

The standard deviation is the square root of the variance. It is sometimes known as the preferred measurement of spread because it has the same units as the mean whereas the variance has squared units. The standard deviation of the data was computed with the formula:

$$
S=\sqrt{S^{2}}=\sqrt{\frac{1}{n}} \sum_{i=1}^{n}(X i+m)^{2}
$$

Where:

$S^{2}=$ Variance

$S=$ Standard deviation

\section{Standard Error}

The standard error associated with the geothermal data are obtained from the standard deviation using the formula:
$S e=\frac{s}{\sqrt{n}}$

Where:

$\mathrm{n}=$ numbers of datasets

$\mathrm{S}_{\mathrm{e}}=$ standard error

$\mathrm{S}=$ standard deviation

\section{Results}

The measured bottom hole temperatures vary between $77-129.9^{\circ} \mathrm{C}$ within the average depth of 2903$4030 \mathrm{~m}$ in the five wells. The measured bottom hole temperature from the wells show that temperature increases with depth. The summary of the computed average geothermal gradient and heat flow statistical values for the wells are shown in Table 1 .

The geothermal gradient map generated for the studied area is shown in Fig. 2. The values are low in the south and high in the northern parts. The values increase towards the north. The least value occurs in the edge of the south east region. Figure 3 is the map of the heat flow distribution. The heat flow also increases from the south towards the north with the least heat flow occurring in the edge of the south east.

Table 1. Summary of computed statistics of geothermal data

\begin{tabular}{llllllc}
\hline Well & $\begin{array}{l}\text { Mean of } \\
\text { geothermal } \\
\text { Gradient }\end{array}$ & $\begin{array}{l}\text { Mean of } \\
\text { heat flow }\end{array}$ & $\begin{array}{l}\text { Variance of } \\
\text { Gradient }\end{array}$ & $\begin{array}{l}\text { Variance of } \\
\text { Heat flow }\end{array}$ & $\begin{array}{l}\text { Standard } \\
\text { deviation } \\
\text { of gradient }\end{array}$ & $\begin{array}{l}\text { Standard } \\
\text { deviation of } \\
\text { Heat flow }\end{array}$ \\
\hline 1 & $23.49 \pm 0.11$ & $51.4 \pm 0.23$ & 0.030 & 0.066 & 0.1730 & 0.256 \\
2 & $17.3 \pm 0.14$ & $38.06 \pm 0.31$ & 0.020 & 0.048 & 0.0100 & 0.220 \\
3 & $24.33 \pm 0.70$ & $53.533 \pm 1.47$ & 0.518 & 2.506 & 0.7200 & 1.583 \\
4 & $23.05 \pm 0.85$ & $51.37 \pm 1.84$ & 1.028 & 5.264 & 1.0140 & 2.294 \\
5 & $23.05 \pm 1.10$ & $56.39 \pm 2.41$ & 0.900 & 4.350 & 0.9481 & 2.085 \\
Mean & $22.24 \pm 0.57$ & $50.15 \pm 1.25$ & 0.499 & 2.447 & 0.790 & 1.564 \\
\hline
\end{tabular}

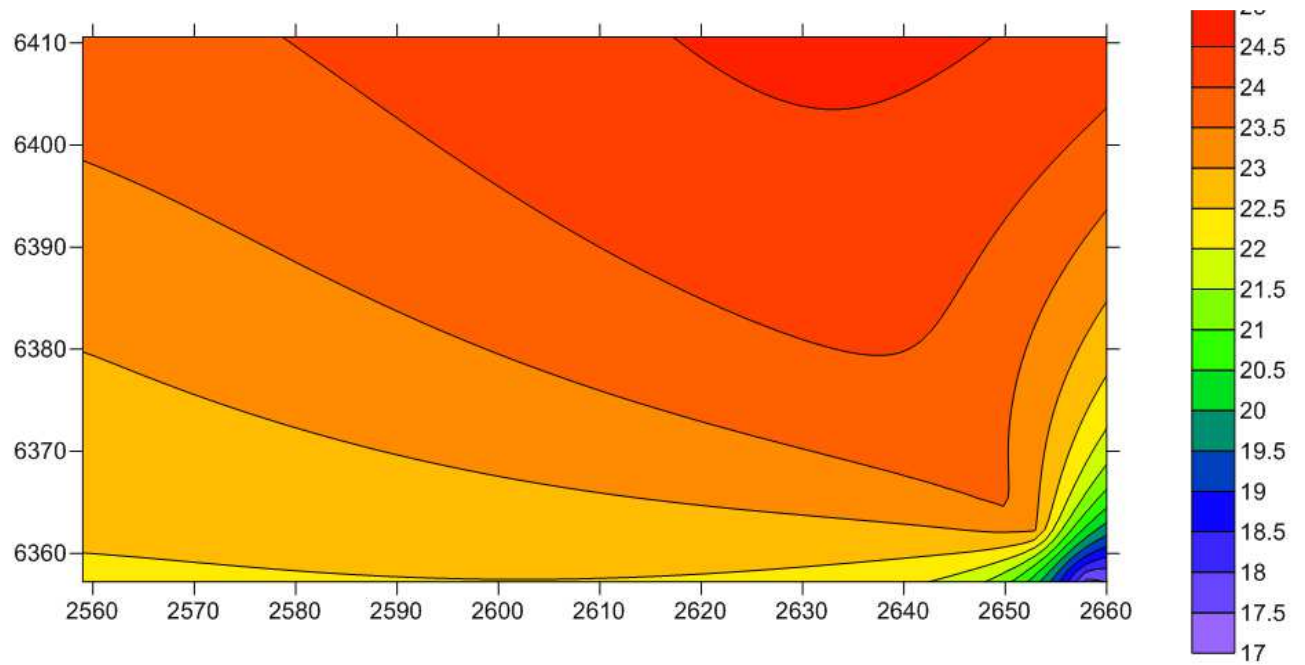

Fig. 2. Map of geothermal gradient of the study field 


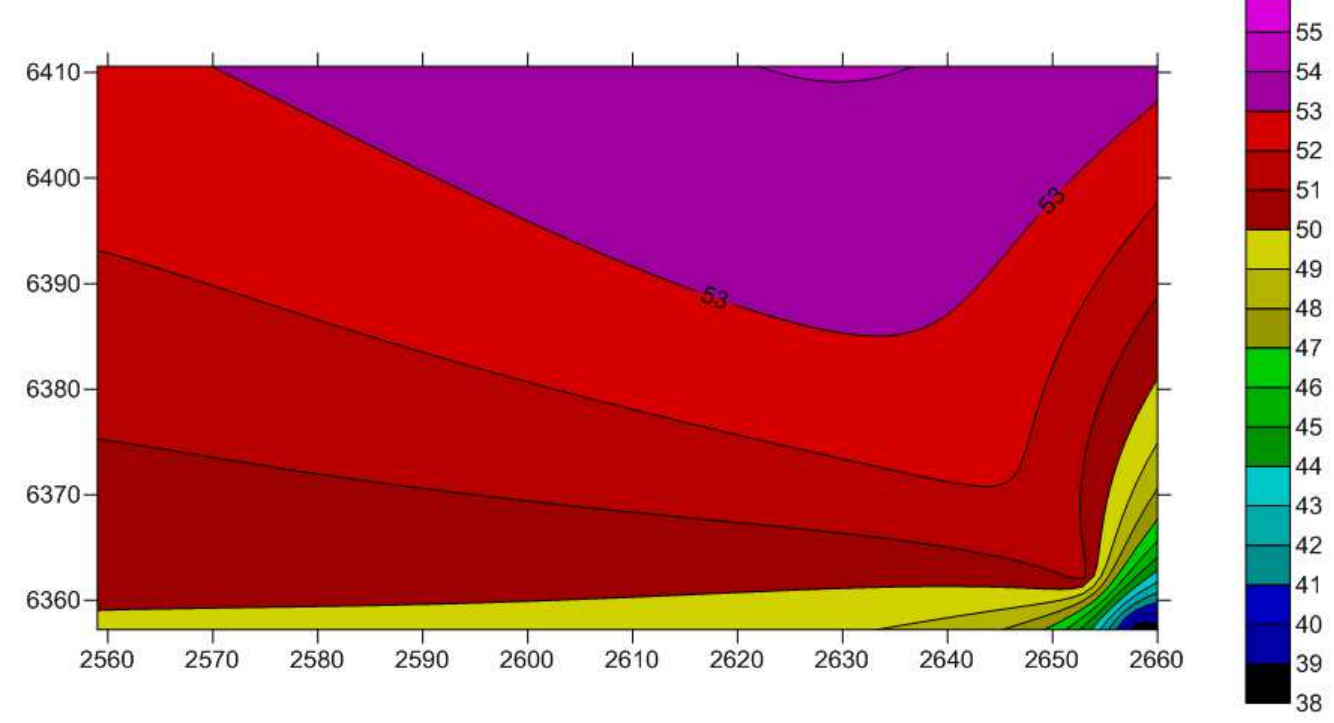

Fig. 3. Map of heat flow in study field

\section{Discussion}

The computed heat flow value ranges between $38.06 \pm 0.31-56.39 \pm 2.41 \mathrm{mWm}^{-2}$ with an average of $50.15 \pm 1.25 \mathrm{mWm}^{-2}$. Similarly, the calculated geothermal gradient ranges from $17.3 \pm 0.14$ to $24.33 \pm 0.70$ with an average of $22.24 \pm 0.57$. The results of the average geothermal gradient and heat flow corresponds with that of previous researchers (Adesida and Ojo, 2004; Akpabio et al., 2003; Emujakporue and Ekine, 2014; Uko et al., 2002). The variance of the geothermal gradient and heat flow are 0.498 and 2.447 respectively. The computed standard deviation for the geothermal gradient and heat flow are $0.573^{\circ} \mathrm{C} / \mathrm{Km}$ and $1.288 \mathrm{mWm}^{-2}$.

The observed temperature anomalies may be largely attributed to the variations in the thermal conductivity of the sediments, thickness of the formations, lithological control and depth to the top of the basement. The variable sediment accumulation in the area has resulted in differences in the overall thermal conductivity of the sediment and the temperature fields reflect such differences. The temperature field is also influenced by gross lithological changes or sedimentation rate. Regions of low thermal anomalies correspond with areas of high sand percentage. It is a very well-known fact that sands are better conductors than shale and will therefore show lower thermal anomalies. The thickness of sand intervals of the Benin and Agbada Formations is another factor that influences thermal anomalies in the area. Minimum temperatures can be attributed to areas of maximum thickness of the sand in Agbada and Benin Formations. Thermal conductivities of the sediments also influence the geothermal pattern in the delta. The possible factors influencing geothermal gradient and heat flow variations in the Niger Delta include; variations in thermal conductivity, sedimentation rates/sediment thicknesses, radiogenic heat production in basement rocks, basal heat flow, large scale water convection and advective flow of fluids.

Some researchers have established an empirical relationship between temperature and hydrocarbon generation (Pusey, 1973; Hunt, 1996). Oil generation normally take place between 65 and $120^{\circ} \mathrm{C}$ while gas generation is between 120 and $225^{\circ} \mathrm{C}$. Within the concept of the hydrocarbon-liquid window, ranges in depth in which liquid hydrocarbons are likely to be present can be determined for any geothermal gradient (Fig. 4). The measured bottom hole temperature in the wells ranges from 77 to $129.9^{\circ} \mathrm{C}$. This is an indication that the sediment in the wells fall within the oil generating window. Assuming that the present temperatures obtained in this study is the maximum values to which the sediments have been subjected, the depths of critical generations and destruction of hydrocarbon in the studied field can be determined on the basis of estimates of geothermal gradient. Thus oil may be generated from a depth range of 2200 to 5900 $\mathrm{m}$ in well 1,2500 to $6100 \mathrm{~m}$ in well 2, 1900 to $5500 \mathrm{~m}$ in well 3, 2500 to $5800 \mathrm{~m}$ in well 4 and 5 (within the range of the two vertical lines in Fig. 4) respectively. Therefore, the geothermal analysis shows that the sediments in the area has attained hydrocarbon generation stage of temperature interval of 150 to $300^{\circ} \mathrm{F}\left(65\right.$ to $\left.150^{\circ} \mathrm{C}\right)$. In the concept of the hydrocarbon-liquid window, the depth range within which liquid hydrocarbons are likely to be present is 1900-6100 m. 


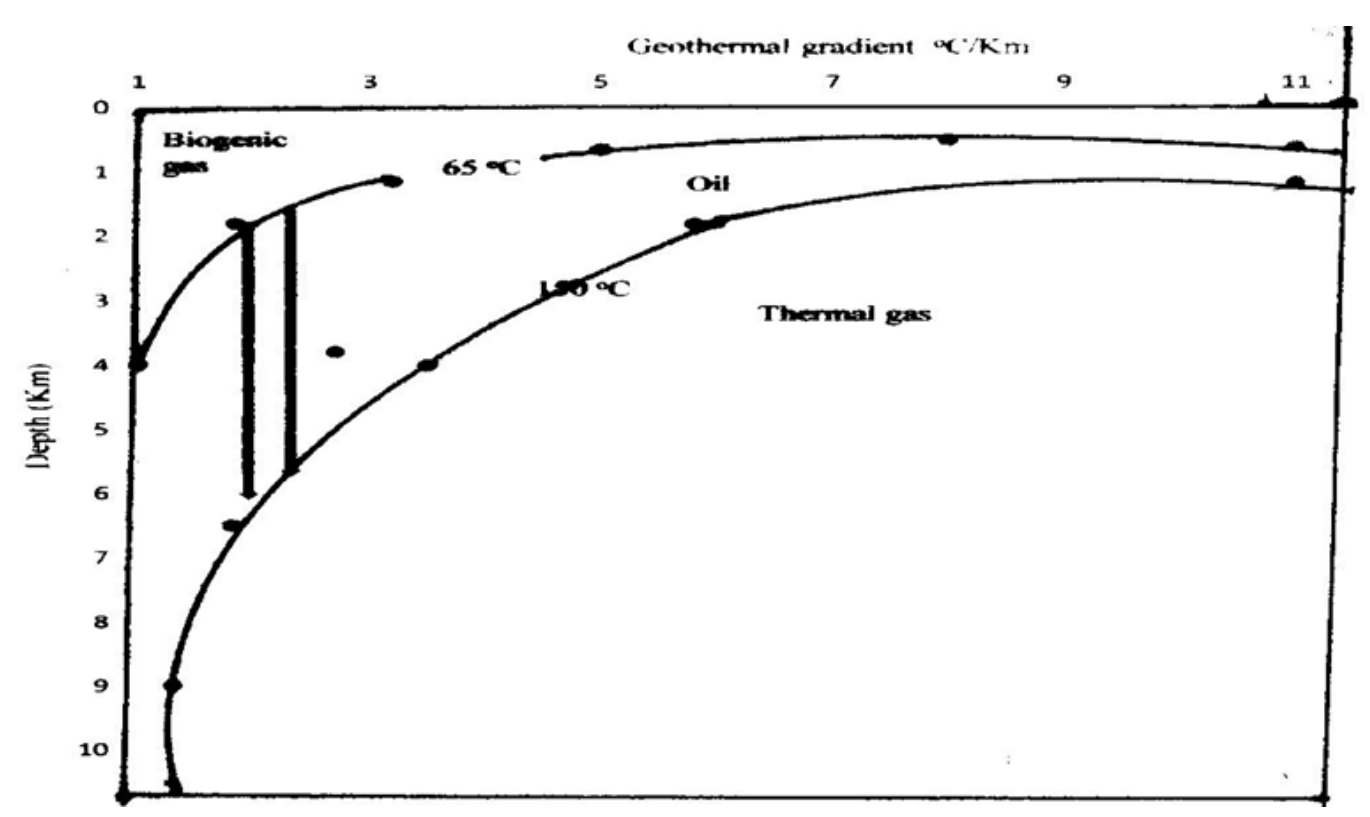

Fig. 4. Hydrocarbon liquid window and theoretical hydrocarbon prospect zone in the studied Area (After Pusey, 1973)

\section{Conclusion}

The statistical analysis of computed geothermal gradient and heat flow for five wells in an oil field, Niger Delta has been discussed. The basic statistical techniques applied to the data are mean, variance, standard deviation and error analysis. The computed geothermal gradient and heat flow vary from $17.3 \pm 0.14$ to $24.33 \pm 0.70^{\circ} \mathrm{C} / \mathrm{Km}$ and $38.06 \pm 0.31$ to $56.39 \pm 2.41$ $\mathrm{mWm}^{-2}$ respectively. The computed variance of the geothermal gradient and heat flow are 0.499 and 2.447 respectively. The standard deviation for the geothermal gradient and heat flow are also 0.79 and 1.564. The geothermal analysis shows that the sediments in the area has attained hydrocarbon generation stage of temperature interval of 150 to $300^{\circ} \mathrm{F}\left(65\right.$ to $\left.150^{\circ} \mathrm{C}\right)$ and the depth range within which liquid hydrocarbons are likely to be present is $1550-4500 \mathrm{~m}$. The statistical analysis has helps in reducing the amount of data, make it easier for conclusions to be taken on the dataset. The statistical study also helps to obtain a quick overview of the dataset and its key characteristics.

\section{Acknowledgement}

We wish to appreciate the Department of Petroleum Resources (DPR) and Agip Petroleum Development Company for providing the data available.

\section{Funding Information}

The project was self sponsors.

\section{Author's Contributions}

Emujakporue Godwin Omokenu: Obtained the data from the company, designed the topic and prepared the manuscript.

Leonard I. Nwosu: Generated and interpreted the maps, read and edited the manuscript.

\section{Ethics}

The article is original, contains unpublished material and has not been published or sent for review elsewhere. The manuscript was read and approved by the authors there is no conflict of interest and ethical issues.

\section{References}

Adesida, A.A., T.J.A. Reijers and C.S. Nwajide, 1997. Sequence stratigraphic framework of the Niger Delta. Am. Associat. Petroleum Geol., 3: 201-219.

Adesida, A. and J.S. Ojo, 2004. Geothermal gradient distribution in Olomoro field, Niger delta. NAPE Bull., 17: 61-69.

Akpabio, I.O., J.E. Ejedavwe, J.O. Ebeniro and E.D. Uko, 2003. Geothermal gradients in the Niger Delta basin from continuous temperature logs. Global J. Pure Applied Sci., 9: 265-271.

DOI: 10.4314 /gjpas.v9i2.15967

Beardsmore, G.R. and J.P. Cull, 2001. Crustal Heat Flow: A Guide to Measurement and Modelling. 1st Edn., Cambridge University Press, Cambridge, ISBN-10: 0521797039, pp: 324.

Avbovbo, A.A., 1978. Tertiary lithostratiphy of Niger Delta. AAPG Bull., 62: 695-306. 
Chukwueke, C., G. Thomas and J. Delfraud. 1992. Sedimentary processes, eustatism, subsidence and heat flow in the distal Part of the Niger Delta. Bull. Centres Rech. Explor. Prod. Elf-Acquitaine, 16: 137-186.

Cressie, N.A.C., 1993. Statistics for Spatial Data. 2nd Edn., John Wiley and Sons, New York, ISBN-10: 0471002550, pp: 900.

Davis, J.C., 1973. Statistics and Data Analysis in Geology. 1st Edn., John Wiley and Sons, New York, ISBN-10: 0471198951, pp: 550.

Ekweozor, C.M. and E.M. Daukoru, 1994. Northern Delta Depobelt Portion of the Akata-Agbada. (1) Petroleum System, Niger Delta, Nigeria, In: The Petroleum System: From Source to Trap, Magom, L.B. and W.G. Dow (Eds.), American Association of Petroleum Geologists, Tulsa, ISBN-10: 0891813381, pp: 599-614.

Emujakporue, G.O. and A.S. Ekine, 2014. Determination of geothermal gradient in the eastern Niger Delta Sedimentary Basin from bottom hole temperatures. J. Earth Sci. Geotechnical Eng., 4: 109-114.

Evamy, B.D., J. Haremboure, P. Kamerling, W.A. Knaap and F.A. Molloy et al., 1978. Hydrocarbon habitat of tertiary Niger Delta. Am. Associat. Petrol. Geol. Bull., 62: 277-298.

Hass, A. and C. Jousselin, 1975. Geostatistics in petroleum industry. Geostat, 75: 333-347. DOI: 10.1007/978-94-010-1470-0_21

Hunt, J.M., 1996. Petroleum Geochemistry and Geology. 2nd Edn., W.H. Freeman, New York, ISBN-10: 0716724413, pp: 743.
Nwachukwu, S.O., 1976. Approximate geothermal gradients in Niger Delta sedimentary basin. AAPG Bull, 60: 1073-1077.

Ogagarue, D. O., 2007. Heat flow estimates in the western Niger Delta Basin, Nigeria. Pacific J. Sci. Technol., 8: 261-266.

Onuoha, K.M. and A.S. Ekine, 1999. Subsurface temperature variations and heat flow in the Anambra basin, Nigeria. J. Afr. Earth Sci., 28: 641-652. DOI: $10.1016 / \mathrm{S} 0899-5362(99) 00036-6$

Pusey, W.C., 1973. How to evaluate potential gas and oil source rocks. World Oil, 176: 71-75.

Reijers, T.J.A., 1996. Selected Chapters on Geology. 1st Edn., SPDC Corporate Reprographic Service, Warri, Nigeria, pp: 197.

Reijers, T.J.A., S.W. Petters and C.S. Nwajide, 1997. The Niger Delta Basin. In: African Basins, Selley, R.C. (Ed.), Elsevier Science, Amsterdam, ISBN-10: 0444825711, pp: 151-172.

Reijers, T.J.A., 2011. Stratigraphy and sedimentology of the Niger Delta. Geologos, 17: 133-162. DOI: $10.2478 / \mathrm{v} 10118-011-0008-3$

Sleep, N.H., 1971. Thermal effects of the formation of atlantic continental margins by continental break up. Geophys. J. Royal Astronamical Society, 24: 325-350. DOI: 10.1111/j.1365-246X.1971.tb02182.x

Uko, E.D., A.R.C. Amakiri and K.O. Alagoa, 2002. Effects of lithology on geothermal gradient on the southeast Nigeria Delta, Nigeria. Global J. Pure Applied Sci., 8: 325-338. DOI: 10.4314/gjpas.v8i3.16016 